\title{
Maximizing rice husk waste for Daucus carota production
}

\author{
K. P. Baiyeri ${ }^{1}$ U. P. Chukwudi ${ }^{1,2}$ (D) C. A. Chizaram ${ }^{1} \cdot$ N. Aneke $^{1}$
}

Received: 7 June 2019 / Accepted: 24 October 2019 / Published online: 6 November 2019

(C) The Author(s) 2019

\begin{abstract}
Purpose Rice husk is one of the most widely available agricultural wastes in many rice producing countries of the world. Here, we evaluated carrot production under different rice husk-amended media aimed at providing alternative use for rice husk.

Methods The experimental design was $2 \times 5 \times 4$ factorial in completely randomized design with six replications. Factor A consist of two production environments—high tunnel and open field while factor B was five growth media—5:0:0, 4:0:1, 3:1:1, 2:2:1 and 1:3:1 (topsoil:rice husk:poultry manure). Factor $\mathrm{C}$ was four carrot varieties; 'Touchon', 'Amazonia', 'Carrot New Kuroda' and 'Touchon Mega'. Data were collected on seedling emergence and yield parameters. The analysed means were separated using $\operatorname{FLSD}_{(0.05)}$.

Results The biomass yield from plants grown in high tunnel was significantly higher than plants in the open field. Highest root weight, wet and dry biomass yield were obtained from medium 4:0:1 followed by 3:1:1. Harvest index ranged from $32.3 \%$ in medium 1:3:1 to $62 \%$ in 3:1:1. Days to seedling emergence among varieties ranged from 8.5 to 11.3. 'Amazonia' variety produced the highest root weight, wet and dry biomass yield and was followed by 'Touchon Mega'.

Conclusion Carrot seedling emergence and yield differed in rice husk-amended media under high tunnel and open field environments. 'Amazonia' variety grown in media 4:0:1 or 3:1:1 gave the best yield. Inclusion of rice husk in media formulation beyond an optimum rate resulted in yield reduction in carrot. Carrot is sensitive to the physio-chemical properties of its growth medium.
\end{abstract}

Keywords Carrot $\cdot$ Dry matter partitioning $\cdot$ Farm by-products $\cdot$ High tunnel $\cdot$ Media formulation $\cdot$ Yield

\section{Introduction}

Increased agricultural production over the years has come at the expense of the ecological sustainability (Yu and $\mathrm{Wu}$ 2018) as tons of agricultural wastes are generated from farm

\footnotetext{
U. P. Chukwudi

uchechukwu.chukwudi@unn.edu.ng; upchukwudi@gmail.com

K. P. Baiyeri

Paul.baiyeri@unn.edu.ng

C. A. Chizaram

chiamakachizaram@gmail.com

N. Aneke

anekenkenna@gmail.com

1 Department of Crop Science, University of Nigeria, Nsukka, Nigeria

2 Department of Crop Science, North-West University, Mafikeng Campus, South Africa
}

by-products and food wastes. Poor handling of waste often results in emission of methane and leachate while open burning by the farmers generate $\mathrm{CO}_{2}$ and other local pollutants. Rice husk is one of the most widely available agricultural wastes in many rice producing countries of the world (Hossain et al. 2018). In every $100 \mathrm{~kg}$ of rice processed, $\approx 20 \mathrm{~kg}$ of rice husk waste is generated (Ghosal and Moulik 2015). Lack of awareness and capacity to convert rice husk into resource material had diminished its usefulness. Developing alternative uses for agricultural wastes will not only increase their values but will help in eliminating their threat to the ecology. One of such alternative use is inclusion as media component in potted plant production. Media composition affects plant growth (Ede et al. 2015) hence; any soil amendment material used in containerized plant production should not disrupt the water, air and nutrient retention capacity of the media. In developing alternative use for rice husk in containerized plant production, there is need to determine the appropriate quantity to be added based on plant need. 
Adubasim et al. (2018) observed positive effect of rice husk in enhancing $\mathrm{pH}$, organic matter, magnesium and available phosphorus as an aerator in media formulation. However, the study did not establish the impact on the media if the aerator (rice husk) quantity was to be increased or decreased. Also, the impact of the aerator is yet to be validated with a test plant.

Carrot (Daucus carota) is a root vegetable with carotenoids, flavonoids, polyacetylenes, vitamins, and minerals, all of which possess numerous nutritional and health benefits (da Silva Dias 2014). In Nigeria, there is high acceptance of carrot root with production common in northern Guinea Savannah and Sudan ecologies where there is drier weather. Edaphic and environmental factors like rainfall and relative humidity often delineate the niche of most plant species. The modification of plant growth environment to increase its production area can occur naturally through evolution and climate change or artificially by erection of protected structures. Protected structures like high tunnels provide organic and conventional growers with an economic means for extending the harvest season of fresh fruits and vegetables in a wide range of climate zones (Gu et al. 2017).

The integration of high tunnel in horticultural production is still at its inception stage in Nigeria, but holds the potential of removing the limitation placed by climate on crop production in the derived Savannah ecology. The derived Savannah ecology is characterized by heavy rainfall, high relative humidity and low insolation. These conditions may not be optimum for carrot production. Sensory and morphological attributes in carrot respond differently to growth environment and genotype (Bach et al. 2015). Understanding the genetic expression of a cultivar in a new environment is vital for its successful introduction.

To our knowledge, virtually no study has assessed the effect of growing carrot in rice husk-amended soil media. Converting rice husk, an agricultural waste, into production resource in an environment not hitherto used for carrot cultivation will not only achieve environmental sanitation, but also food security with potentials of poverty reduction. Having this mindset, this study was initiated to assess emergence and yield of four varieties of carrot in rice huskamended media under high tunnel and open field production environments.

\section{Materials and methods}

\section{Description of experimental site}

The experiment was performed in 2014 and 2015 at the Teaching and Research Farm of the Department of Crop Science, University of Nigeria, Nsukka campus Enugu State, Nigeria. The experimental site is located at $06^{\circ} 52^{\prime} \mathrm{N}$, $07^{\circ} 24^{\prime} \mathrm{E}$ and is about $447 \mathrm{~m}$ above sea level. Nsukka is in the derived Savannah ecology. The area is characterized by lowland humid conditions with bimodal annual rainfall distribution that ranged from 1155 to $1955 \mathrm{~mm}$. Its mean annual temperature ranged from 29 to $31^{\circ} \mathrm{C}$ with relative humidity of $69-79 \%$.

\section{Experimental design and formulation of media}

The experimental design used was $2 \times 5 \times 4$ factorial experiment fitted into in a completely randomized design with six replications. Factor A consist of two production environments namely high tunnel and open field while factor B was five growth media namely 5:0:0, 4:0:1, 3:1:1, 2:2:1 and 1:3:1. Factor C comprises four carrot varieties; 'Touchon', 'Amazonia', 'Carrot New Kuroda' and 'Touchon Mega'.

The media were formulated on volume ratios of topsoil, rice husk and poultry manure. The topsoil was obtained from the experimental site at the depth of $0-30 \mathrm{~cm}$. The experimental soil is classified as ultisol according to the soil taxonomy of the USDA (Soil Survey Staff 2014). Chukwudi and Agbo (2014) described the soil as sandy clay loam having low organic carbon content of about $1.46 \%$ with low nitrogen, phosphorous, potassium, magnesium, calcium and base saturation contents and high exchangeable acidity. The rice husk was sourced from a rice mill at Adani Rice Farm settlement while the poultry manure was obtained from the poultry unit of the University farm, all located in Enugu State, Nigeria. The topsoil, rice husk and poultry manure were dried, sieved and homogenized before been used for the media formulations. As the aim of the study was to assess the suitability of rice husk-amended soil in carrot production, different volumes of topsoil were replaced with rice husk in three media while maintaining topsoil + rice husk + poultry manure ratio (vol./vol./vol.). Among the two media used as control (without rice husk amendment), one contained topsoil + poultry manure while the other contained only topsoil. The media were mixed as follows:

1. 4:0:1 (topsoil:rice husk:poultry manure)

2. 3:1:1 (topsoil:rice husk:poultry manure)

3. 2:2:1 (topsoil:rice husk:poultry manure)

4. 1:3:1 (topsoil:rice husk:poultry manure)

5. 5:0:0 (topsoil:rice husk:poultry manure).

Each medium was bagged and labelled properly after mixing. The media were kept out of rain and periodically turned to ensure uniform decomposition. After 13 weeks of decomposition, equal volume of each mixture was transferred to plastic planting pots $(14 \mathrm{~cm}$ length $\times 12 \mathrm{~cm}$ diameter) perforated at the base for drainage. The use of volume was to remove the variation caused by the different amount of soil in each growth media. Two hundred and forty 
$(4 \times 2 \times 5 \times 6)$ planting pots were used for the study. The four carrot varieties seeds were planted in the different media and placed in the high tunnel and open field. The study was done during the dry season and a uniform irrigation was applied to the plants.

\section{Data collection}

The number of days to seedling emergence was monitored after planting. Three months after planting when the roots had turned bright orange colour the plants were harvested. Plants from three buckets in each treatment were randomly selected for harvest index determination and number of forks was counted. The selected plants were individually weighed using a digital scale to determine the wet biomass yield. The roots (economic yield) were separated from above ground plant parts and weighed. The roots and above ground plant parts were oven dried at $70{ }^{\circ} \mathrm{C}$ to constant weight to ascertain the dry matter accumulation (dry biomass yield). The economic yield and wet biomass yield were used in the calculation of harvest index on fresh weight basis using the following equation (Smith et al. 2018): Harvest index $(\%)=($ economic yield /biological yield $) \times 100$.

\section{Laboratory analyses}

Samples of the formulated growth media were taken to the laboratory unit for physical and chemical analyses. Media $\mathrm{pH}$, organic matter content, nitrogen content, available phosphorus, exchangeable bases $\left(\mathrm{K}^{+}, \mathrm{Na}^{+}, \mathrm{Ca}^{2+}\right.$ and $\left.\mathrm{Mg}^{2+}\right)$, acidity and cation exchange capacity were determined as described by Estefan et al. (2013). Base saturation was calculated as the ratio of the four exchangeable bases to the effective cation exchange capacity (e-CEC), being the sum of the exchangeable bases and the exchangeable acidity.

\section{Data analysis}

The collected data were subjected to analysis of variance (ANOVA) according to the procedure outlined for factorial experiment in completely randomized design using GenStat software (GenStat 2011). Fisher's least significant difference (F-LSD) at 5\% level of probability was used to separate means when there was a significant $F$ test in the ANOVA table.

\section{Results and discussion}

\section{Media composition}

The result of the physical analysis of the various media showed no difference in their textural class. They had a common textural class of sandy loamy, however the highest clay content was found in 5:0:0 while the least was recorded in 2:2:1 and 1:3:1 (Table 1).

The percentage clay content decreased as the volume of topsoil decreased. Substituting topsoil with rice husk decreased the coarse sand content and increased the fine sand content of the media. The highest fine sand and lowest coarse sand were obtained from medium 1:3:1. The organic matter content, total nitrogen and CEC of the media increased with addition of rice husk. Adubasim et al. (2018) reported marginal increase in total nitrogen, available phosphorus and organic matter content of soil-based nursery media amended with rice husk. Besides being of high nutrient content and moisture retention capacity, rice husk is a good aerator (Adubasim et al. 2018; Baiyeri and Mbah 2006). The $\mathrm{pH}$ is an important index of chemical quality and horticultural value of nursery media (Adubasim et al. 2018). In this study, the $\mathrm{pH}$ results showed that the soil of the experimental site was acidic in nature. The highest $\mathrm{pH}$ values $\left(\mathrm{H}_{2} \mathrm{O}\right.$ and $\left.\mathrm{KCl}\right)$ were obtained when the soil was amended with poultry manure without rice husk (medium 4:0:1). Among the rice husk-amended media, adding one volume of rice husk $(3: 1: 1)$ produced the lowest $\mathrm{pH}$ of 6.8 in water and $6.4 \mathrm{in} \mathrm{KCl}$. Inclusion of rice husk with poultry manure in the growth media neutralized the acidity of the topsoil to slightly acidic/neutral pH level. Earlier studies (Baiyeri and Mbah 2006; Islabão et al. 2014) showed that rice husk and rice husk ash were effective in reducing soil acidity under greenhouse and field conditions, respectively. Slightly acidic soil promotes plant root growth and increases nutrient availability (Taiz and Zeiger 2014).

Table 1 Chemical properties of the rice husk-amended soil media and controls

\begin{tabular}{|c|c|c|c|c|c|c|c|c|c|c|c|c|c|}
\hline Media & $\mathrm{pH} \mathrm{H} \mathrm{H}_{2} \mathrm{O}$ & $\mathrm{pH} \mathrm{KCl}$ & $\mathrm{OM}(\%)$ & $\mathrm{TN}(\%)$ & $\mathrm{Na}^{+}$ & $\mathrm{K}^{+}$ & $\mathrm{Ca}^{2+}$ & $\mathrm{Mg}^{2+}$ & CEC & $\mathrm{BS}(\%)$ & $\mathrm{Al}^{3+}$ & $\mathrm{H}^{+}$ & Av. P \\
\hline 4:0:1 & 7.5 & 7.1 & 3.51 & 0.21 & 0.261 & 0.26 & 7.0 & 4.0 & 14 & 82.27 & - & 1.6 & 45.70 \\
\hline $3: 1: 1$ & 6.8 & 6.4 & 4.51 & 0.25 & 0.263 & 0.27 & 6.0 & 6.0 & 17.2 & 72.85 & - & 1.0 & 55.96 \\
\hline $2: 2: 1$ & 7.3 & 7.0 & 10.11 & 0.36 & 0.231 & 0.22 & 3.0 & 9.0 & 24.4 & 53.49 & - & 1.4 & 76.48 \\
\hline $1: 3: 1$ & 6.7 & 6.6 & 11.59 & 0.38 & 0.231 & 0.19 & 3.0 & 9.8 & 22.4 & 59.92 & - & 2.2 & 75.55 \\
\hline 5:0:0 & 4.6 & 4.3 & 1.42 & 0.07 & 0.181 & 0.21 & 1.4 & 0.8 & 13.2 & 19.61 & 0.8 & 1.2 & 13.99 \\
\hline
\end{tabular}

$O M$ organic matter, $T N$ total nitrogen, $C E C$ cation exchange capacity $\left(\mathrm{cmol} \mathrm{kg}^{-1}\right), B S$ base saturation, $A v$. $P$ available phosphorus 


\section{Effects of environment, media and variety on the seedling emergence of carrot}

The number of days to seedling emergence in carrot as influenced by environments, media and varieties are presented in Table 2.

Carrot seeds planted in the high tunnel emerged faster than seeds planted in the open field. Growth media significantly influenced the number of days to seedling emergence of the carrots with medium 5:0:0 producing the least number of days to seedling emergence which was similar to medium $1: 3: 1$. They were followed by medium $3: 1: 1$. The highest number of days to seedling emergence was obtained from medium 4:0:1, followed by media 2:2:1. However, the difference between the medium that produced the least (medium 5:0:0) and highest (medium 4:0:1) number of days to seedling emergence was less than a day. Among the varieties, the number of days to seedling emergence ranged from 8.5 in 'Carrot New Kuroda' to 11.3 in 'Amazonia' variety. The least number of days to seedling emergence in 'Carrot New Kuroda' was significantly lower than the other varieties and was followed by 'Touchon' variety with 9 days. 'Amazonia' variety gave the highest number of days to seedling emergence that was similar to 'Touchon Mega' variety.

All the first-order interaction had significant effect on number of days to seedling emergence (Table 3 ). The second-order interaction also showed significant effect of environment, growth media and variety on number of days to seedling emergence which ranged from 8 to 12 days (Table 4). The least significant number of days to seedling emergence (8) was obtained from 'Carrot New Kuroda' grown across the five media in the high tunnel. The highest number of days to seedling emergence was obtained from 'Touchon Mega' grown in medium 4:0:1 under the high tunnel. The same number of days was obtained from 'Touchon Mega' and 'Amazonia' varieties grown in media 4:0:1, 3:1:1, 2:2:1 and 1:3:1 in the open field.

The applied treatments influenced carrot seedling emergence as indicated by the observed significant effects. Time to seedling emergence is the result of a complex interaction of ambient weather conditions, soil, seed and seedling characteristics (Mackenzie et al. 2016). This interaction can be influenced by the production environment which might improve or reduce seedling emergence.
Table 2 Main effects of environment, media and varieties on carrot emergence and yield attributes
Table 3 First-order interaction of environment, media and variety on carrot emergence and yield attributes

\begin{tabular}{lrlllll}
\hline Environment & DSE & HI $(\%)$ & BYw $(\mathrm{g})$ & BYd $(\mathrm{g})$ & ANR & ARw $(\mathrm{g})$ \\
\hline High tunnel & 9.73 & 52.2 & 8.7 & 1.6 & 2.9 & 5.04 \\
Open field & 10.31 & 55.4 & 7.6 & 1.3 & 2.9 & 4.81 \\
FLSD $_{(0.05)}$ & 0.07 & $\mathrm{~ns}$ & 0.8 & 0.2 & $\mathrm{~ns}$ & $\mathrm{~ns}$ \\
Media & & & & & & \\
4:0:1 & 10.21 & 61.1 & 14.6 & 2.3 & 2.9 & 8.77 \\
$3: 1: 1$ & 10.04 & 62.0 & 9.8 & 1.7 & 3.0 & 6.41 \\
2:2:1 & 10.10 & 53.5 & 7.2 & 1.3 & 3.0 & 4.01 \\
$1: 3: 1$ & 9.90 & 32.3 & 1.7 & 0.4 & 2.8 & 0.69 \\
$5: 0: 0$ & 9.85 & 60.0 & 7.4 & 1.6 & 2.8 & 4.75 \\
FLSD & 0.12 & 5.5 & 1.3 & 0.4 & $\mathrm{~ns}$ & 0.89 \\
Variety & & & & & & \\
'Touchon' & 9.00 & 59.9 & 7.2 & 1.4 & 2.9 & 4.86 \\
'Amazonia' & 11.32 & 57.6 & 11.3 & 2.4 & 3.0 & 7.17 \\
'Carrot New Kuroda' & 8.50 & 49.9 & 4.7 & 0.5 & 2.9 & 2.51 \\
'Touchon Mega' & 11.27 & 47.7 & 9.4 & 1.6 & 2.8 & 5.16 \\
FLSD $_{(0.05)}$ & 0.10 & 4.9 & 1.2 & 0.3 & $\mathrm{~ns}$ & 0.80 \\
\hline
\end{tabular}

$D S E$ number of days to seedling emergence, $H I$ harvest index, $B Y w$ wet biomass yield, $B Y d$ dry biomass yield, $A N R$ average number of roots, $A R w$ average root weight, $n s$ non-significant

\begin{tabular}{llllllll}
\hline & & DSE & HI $(\%)$ & BYw $(\mathrm{g})$ & BYd $(\mathrm{g})$ & ANR & ARw $(\mathrm{g})$ \\
\hline Environment & Media & $*$ & $*$ & $*$ & $\mathrm{~ns}$ & $\mathrm{~ns}$ & $*$ \\
Environment & Variety & $*$ & $\mathrm{~ns}$ & $\mathrm{~ns}$ & $*$ & $\mathrm{~ns}$ & $\mathrm{~ns}$ \\
Media & Variety & $*$ & $*$ & $*$ & $*$ & $\mathrm{~ns}$ & $*$ \\
\hline
\end{tabular}

$D S E$ number of days to seedling emergence, $H I$ harvest index, $B Y w$ wet biomass yield, $B Y d$ dry biomass yield, $A N R$ average number of roots, $A R w$ average root weight, * significant, $n s$ non-significant 
Table 4 Second-order interaction of environment, media and variety on carrot emergence and yield attributes

\begin{tabular}{|c|c|c|c|c|c|c|c|c|}
\hline Environment & Media & Variety & DSE & $\mathrm{HI}(\%)$ & BYw (g) & BYd (g) & ANR & $\mathrm{ARw}(\mathrm{g})$ \\
\hline High tunnel & 4.0 .1 & 'Touchon' & 9.0 & 69.3 & 13.23 & 2.47 & 3.0 & 9.13 \\
\hline High tunnel & 4.0 .1 & 'Amazonia' & 10.7 & 59.4 & 21.20 & 4.99 & 3.0 & 12.6 \\
\hline High tunnel & 4.0 .1 & 'CNK' & 8.0 & 50.8 & 7.08 & 0.30 & 2.7 & 3.58 \\
\hline High tunnel & 4.0 .1 & 'Touchon Mega' & 12.0 & 50.9 & 23.74 & 2.57 & 2.7 & 12.09 \\
\hline High tunnel & 3.1 .1 & ‘Touchon' & 9.0 & 70.7 & 8.51 & 1.00 & 3.0 & 6.04 \\
\hline High tunnel & 3.1 .1 & 'Amazonia' & 11.8 & 68.1 & 15.37 & 2.73 & 3.0 & 10.39 \\
\hline High tunnel & 3.1 .1 & 'CNK' & 8.0 & 46.0 & 4.24 & 0.42 & 3.0 & 1.94 \\
\hline High tunnel & 3.1 .1 & ‘Touchon Mega' & 10.8 & 70.3 & 16.83 & 3.96 & 3.0 & 11.81 \\
\hline High tunnel & 2.2 .1 & 'Touchon' & 9.0 & 56.8 & 5.32 & 0.77 & 3.0 & 3.00 \\
\hline High tunnel & 2.2 .1 & 'Amazonia' & 11.2 & 54.5 & 5.95 & 1.92 & 3.0 & 3.24 \\
\hline High tunnel & 2.2 .1 & 'CNK' & 8.0 & 35.5 & 4.43 & 0.70 & 3.0 & 1.61 \\
\hline High tunnel & 2.2 .1 & ‘Touchon Mega' & 10.7 & 39.6 & 8.07 & 1.43 & 3.0 & 3.15 \\
\hline High tunnel & 1.3 .1 & 'Touchon' & 9.0 & 45.3 & 2.58 & 0.50 & 2.7 & 1.24 \\
\hline High tunnel & 1.3 .1 & 'Amazonia' & 11.0 & 32.3 & 2.90 & 1.20 & 2.7 & 1.16 \\
\hline High tunnel & 1.3 .1 & 'CNK' & 8.0 & 32.3 & 2.54 & 0.27 & 3.0 & 0.82 \\
\hline High tunnel & 1.3 .1 & ‘Touchon Mega' & 10.2 & 45.3 & 2.99 & 0.74 & 3.0 & 1.35 \\
\hline High tunnel & 5.0 .0 & 'Touchon' & 9.0 & 58.7 & 5.21 & 1.95 & 3.0 & 3.21 \\
\hline High tunnel & 5.0 .0 & 'Amazonia' & 10.7 & 60.0 & 14.37 & 3.40 & 3.0 & 8.61 \\
\hline High tunnel & 5.0 .0 & 'CNK' & 8.0 & 62.7 & 8.90 & 0.77 & 3.0 & 5.57 \\
\hline High tunnel & 5.0 .0 & 'Touchon Mega' & 10.7 & 35.3 & 0.80 & 0.10 & 3.0 & 0.31 \\
\hline Open field & 4.0 .1 & 'Touchon' & 9.0 & 70.1 & 12.82 & 2.04 & 3.0 & 9.03 \\
\hline Open field & 4.0 .1 & 'Amazonia' & 12.0 & 72.4 & 13.70 & 2.99 & 3.0 & 9.78 \\
\hline Open field & 4.0 .1 & 'CNK' & 9.0 & 64.0 & 9.76 & 1.38 & 3.0 & 6.24 \\
\hline Open field & 4.0 .1 & 'Touchon Mega' & 12.0 & 51.6 & 14.95 & 1.49 & 3.0 & 7.70 \\
\hline Open field & 3.1 .1 & ‘Touchon' & 9.0 & 74.1 & 9.66 & 1.74 & 3.0 & 7.13 \\
\hline Open field & 3.1 .1 & 'Amazonia' & 10.7 & 61.8 & 10.44 & 1.78 & 3.0 & 6.49 \\
\hline Open field & 3.1 .1 & 'CNK' & 9.0 & 49.2 & 3.73 & 0.47 & 3.0 & 1.89 \\
\hline Open field & 3.1 .1 & ‘Touchon Mega' & 12.0 & 56.2 & 9.87 & 1.89 & 3.0 & 5.56 \\
\hline Open field & 2.2 .1 & ‘Touchon' & 9.0 & 74.1 & 9.66 & 1.74 & 3.0 & 7.13 \\
\hline Open field & 2.2 .1 & 'Amazonia' & 12.0 & 61.8 & 10.44 & 1.78 & 3.0 & 6.49 \\
\hline Open field & 2.2 .1 & 'CNK' & 9.0 & 49.2 & 3.73 & 0.47 & 3.0 & 1.89 \\
\hline Open field & 2.2 .1 & 'Touchon Mega' & 12.0 & 56.2 & 9.87 & 1.89 & 3.0 & 5.56 \\
\hline Open field & 1.3 .1 & ‘Touchon' & 9.0 & 18.3 & 0.58 & 0.10 & 2.7 & 0.11 \\
\hline Open field & 1.3 .1 & 'Amazonia' & 12.0 & 34.2 & 1.09 & 0.22 & 3.0 & 0.39 \\
\hline Open field & 1.3 .1 & 'CNK' & 9.0 & 44.8 & 0.95 & 0.20 & 3.0 & 0.45 \\
\hline Open field & 1.3 .1 & 'Touchon Mega' & 11.0 & 18.0 & 0.39 & 0.05 & 2.3 & 0.07 \\
\hline Open field & 5.0 .0 & 'Touchon' & 9.0 & 61.9 & 4.08 & 1.48 & 2.7 & 2.58 \\
\hline Open field & 5.0 .0 & 'Amazonia' & 11.2 & 71.1 & 17.60 & 2.97 & 3.0 & 12.54 \\
\hline Open field & 5.0 .0 & 'CNK' & 9.0 & 64.7 & 1.69 & 0.26 & 2.7 & 1.10 \\
\hline Open field & 5.0 .0 & ‘Touchon Mega' & 11.3 & 65.6 & 6.19 & 1.69 & 2.3 & 4.07 \\
\hline $\operatorname{FLSD}_{(0.05)}$ & & & 0.3 & 15.58 & 3.72 & 1.04 & ns & 2.53 \\
\hline
\end{tabular}

$D S E$ number of days to seedling emergence, $H I$ harvest index, $B Y w$ wet biomass yield, $B Y d$ dry biomass yield, $A N R$ average number of roots, $A R w$ average root weight, ' $C N K$ ' Carrot New Kuroda, $n s$ non-significant
Modified environment like the high tunnel affects plant growth (O'Connell et al. 2012). In carrot, modified environment improved seedling emergence as was observed in this study. This assertion aligns with the findings of Rekika et al. (2008) that 'floating rowcover' reduced seedling emergence time in carrot. Similarly, growth media influenced seedling emergence in this study. Significant effect of growth media on seedling emergence had been reported for Moringa oleifera (Ede et al. 2015), Musa species (Baiyeri and Aba, 2013) and Treculia africana (Baiyeri and Mbah 2006). 


\section{Effects of environment, media and variety on the yield components of carrot}

The main effects of environments, growth media and varieties on the yield components of carrot are presented in Table 2. The high tunnel was significantly higher than the open field in wet and dry biomass yield however, environment had no significant effect on harvest index, number of roots and root weight. Similar to seedling emergence, the growth media influenced the yield components. Medium 4:0:1 was significantly higher than the other growth media in wet and dry biomass yield and was followed by medium $3: 1: 1$. A range of $32.3 \%$ in medium $1: 3: 1$ to $62 \%$ in medium 3:1:1 was obtained for growth media harvest index. The harvest index from medium 3:1:1 was statistically similar to media 4:0:1 and 5:0:0. The root weight of carrot harvested from medium 4:0:1 was significantly higher than other growth media and was followed by medium 3:1:1. Harvest index, root weight, wet and dry biomass yield decreased as the volume of rice husk increased.

Harvest index as influenced by varieties ranged from 47.7\% in 'Touchon Mega' to 59.9\% in 'Touchon'. There was no significant difference between 'Touchon' and 'Amazonia' varieties in harvest index. However, 'Amazonia' variety was significantly higher than the other varieties in root weight, wet and dry biomass yield. It was followed by 'Touchon Mega' variety in these parameters. The root weight values ranged from $2.5 \mathrm{~g}$ in 'Carrot New Kuroda' to $7.2 \mathrm{~g}$ in 'Amazonia'.

The first-order interaction revealed that environment $\mathrm{x}$ growth media had significant effect on harvest index, wet biomass yield and root weight (Table 3 ). Environment $\times$ variety had significant effect on dry biomass yield while growth media $\times$ variety interaction had significant effect on harvest index, wet and dry biomass yield and root weight.

The second-order interaction presented in Table 4 showed significant effect of environment, growth media and variety on harvest index, root weight, wet and dry biomass yield. The highest harvest index of $74.1 \%$ was produced by 'Touchon' variety grown in media 3:1:1 and 2:2:1 in the open field. The harvest index values ranged from $18 \%$ to $74.1 \%$. 'Touchon Mega' variety grown in medium 4:0:1 in the high tunnel gave the highest wet biomass weight of $23.7 \mathrm{~g}$ that was significantly higher than the other treatment combinations but similar to 'Amazonia' grown in the same medium and environment. They were followed by 'Amazonia' grown in medium 5:0:0 in the open field and 'Touchon Mega' grown in medium 3:1:1 in the high tunnel. On dry biomass yield, 'Amazonia' variety grown in medium 4:0:1 in the high tunnel gave the highest weight that was significantly higher than the other treatment combinations but similar to 'Touchon Mega' grown in medium 3:1:1 in the same environment. The difference observed in the root weights of the carrot followed a similar trend with the wet biomass yield result. 'Amazonia' variety grown in media 4:0:1 in the high tunnel gave the highest root weight that was significantly higher than most of the other treatment combinations except 'Touchon Mega' grown in media 3:1:1 and 4:0:1; 'Amazonia' grown in medium 3:1:1 in the high tunnel and 'Amazonia' grown in medium 5:0:0 in the open field. 'Touchon Mega' grown in medium 1:3:1 in the open field gave the lowest values for harvest index, root weight, wet and dry biomass yields.

The identified significant differences in yield components among the carrot varieties are an indication that the applied treatments influenced carrot production. The high tunnel improved the growth and dry matter accumulation in carrot over the open field implying environmental influence on the biomass yield, but not on dry matter partitioning in carrot as reflected on harvest index, number of roots and root weight. However, dry matter accumulation and partitioning were influenced by growth media. Dry matter partitioning is influenced by the sink strength of an organ; its ability to compete for assimilates and the developmental stage of the plant (Chukwudi and Agbo 2016). Availability of assimilates, rate of assimilate remobilisation from source tissues, genotype and developmental stage of the plant also determine the dry matter partitioning in plants (Chukwudi and Agbo 2016; Smith et al. 2018). Continuous cell division and expansion of carrot root during growth gives it an edge to accumulate available assimilates. Therefore, restriction of carrot root during growth results in hard and misshapen roots (Sudeshika et al. 2018) and will favour translocation of assimilates to other plant parts. Volume of soil structure modification, nutrients accumulation zones, available water and air as well as microbial community influence water and nutrient uptake by plant roots (York et al. 2016).

As expected, the clay content of the growth media decreased with reduction in the volume of topsoil used visà-vis increase in rice husk used. Inclusion of rice husk in this study increased the organic matter content of the media which in turn improved the $\mathrm{pH}$ value, percentage nitrogen and CEC. Reduction in clay content may account for the best harvest index recorded in medium 3:1:1. High clay content causes surface crust when there is no moisture while excess moisture results in soggy soil. Increase in soil $\mathrm{pH}$ towards neutrality makes nutrient more available to plants and improves CEC thereby improving plant growth (Major et al. 2010; Munda et al. 2016). Rice husk increases organic matter content of planting medium when used as soil amendment (Adubasim et al. 2018; Mishra et al. 2017).

Dry matter partitioning in carrots grown in medium $3: 1: 1$ accumulated more in the economic portion (roots) than other plant parts. Increasing the quantity of rice husk used in media formulation caused reduction in harvest index and biomass yield of carrot. This reduction in yield was consistent with 
the report of Mishra et al. (2017) in their study of rice growth and yield using different rates of rice husk and rice husk charcoal. This is an indication that there is an optimum rate of rice husk to be included as soil amendment substrate. Beyond this optimum rate, decline in growth and yield will occur as was observed in medium 1:3:1. This medium contained the highest quantity of rice husk in this study and was consistently low in harvest index, root weight, wet and dry biomass yield. Though rice husk had been associated with high carbon nitrogen ratio, a ratio of $1: 1$ of rice husk to poultry manure released adequate nutrient for potted carrot production. Base materials for formulating potting media are significant determinants of its physio-chemical properties (Baiyeri 2003) which influence the quality of plants obtained from the media (Baiyeri and Mbah 2006). Our study showed that carrot is sensitive to the physiochemical properties of its growth medium. Sudeshika et al. (2018) reported significant effect of coir dust and compost growth media on vegetative and yield performances of carrot.

The second-best biomass yield obtained from medium 3:1:1 after medium 4:0:1 showed that rice husk can be converted from agricultural waste to useful substrate in carrot production. Rice husk has the potential to be used as a soil amendment due to its high content of silicon and potassium nutrients and its ability to improve soil porosity (Jeon et al. 2010; Varela et al. 2013).

The genetic variability in the four carrot varieties was expressed in their seedling emergence, biomass yield, harvest index and root weight. These expressed genetic variabilities are in line with earlier studies (Seljåsen et al. 2012, 2013) on factors accounting for differences in carrot. 'Amazonia' variety gave the highest root weight, wet and dry biomass yield and was followed by 'Touchon Mega' variety in these parameters. In this study, harvest index was influenced more by the growth media and carrot variety than the growth environment. Growing different varieties of carrot in rice husk-amended media confirmed that media of carrot growth influences the extent to which the plant expresses its genetic potential. This was pronounced in 'Touchon Mega' variety. 'Touchon Mega' grown in media 3:1:1 and 4:0:1 in the high tunnel was either highest or similar to the highest mean in harvest index, biomass yield and root weight however, when grown in media 1:3:1 in the open field it gave the least values for these parameters. There were variations within varieties when exposed to different growth media and environment. Biomass yield in this study was influenced by the growth environment, media and carrot variety used.

\section{Conclusion}

Carrot seedling emergence and yield parameters differed in rice husk-amended media under high tunnel and open field environments. The organic matter content, total nitrogen and CEC of the media increased with addition of rice husk. However, further increase of rice husk in the growth media beyond an optimum rate resulted in yield reduction. This is an indication that carrot is sensitive to the physio-chemical properties of its growth medium. Based on the yield parameters measured, medium 4:0:1 gave the best result and was followed by medium 3:1:1. 'Amazonia' variety is recommended for cultivation in the study location due to its superior yield performance. We recommend a cost benefit study of using high tunnel structures for carrot production to assess if the extra yield obtained from it is commensurate to the cost of construction and maintenance. High tunnel may be used in carrot production if it does not reduce the profit margin.

Open Access This article is distributed under the terms of the Creative Commons Attribution 4.0 International License (http://creativeco mmons.org/licenses/by/4.0/), which permits unrestricted use, distribution, and reproduction in any medium, provided you give appropriate credit to the original author(s) and the source, provide a link to the Creative Commons license, and indicate if changes were made.

\section{References}

Adubasim C, Igwenagu C, Josiah G, Obalum S, Okonkwo U, Uzoh I, Sato S (2018) Substitution of manure source and aerator in nursery media on sandy loam topsoil and their fertility indices 4 months after formulation. Int J Recycl Org Waste Agric 7:305312. https://doi.org/10.1007/s40093-018-0216-8

Bach V, Kidmose U, Kristensen HL, Edelenbos M (2015) Eating quality of carrots (Daucus carota L.) grown in one conventional and three organic cropping systems over 3 years. J Agric Food Chem 63:9803-9811. https://doi.org/10.1021/acs.jafc.5b03161

Baiyeri KP (2003) Evaluation of nursery media for seedling emergence and early seedling growth of two tropical tree species. Moor J Agric Res 4:60-65. https://doi.org/10.4314/mjar.v4i1.31754

Baiyeri KP, Aba SC (2013) Physicochemical characteristics of nursery media formulated from organic wastes influenced growth and drymatter yield of banana (Musa AA var. Pisang lilin) plantlets. Niger J Hort Sci 17:135-145

Baiyeri KP, Mbah BN (2006) Effects of soilless and soil-based nursery media on seedling emergence, growth and response to water stress of African breadfruit (Treculia Africana Decne). Afr J Biotechnol 5:1405-1410

Chukwudi UP, Agbo CU (2014) Effect of trellis height and cutting frequency on leaf and fruit yield of fluted pumpkin (Telfairia occidentalis Hook F.). J Anim Plant Sci 24:1190-1197

Chukwudi UP, Agbo CU (2016) Characterization and preliminary evaluation of local germplasm of Telfairia occidentalis Hook F. accessions in Enugu, Nigeria. Agro-Sci 15:15-22. https://doi. org/10.4314/as.v15i2.3

da Silva Dias JC (2014) Nutritional and health benefits of carrots and their seed extracts. Food Nutr Sci 5:2147-2156. https://doi. org/10.4236/fns.2014.522227

Ede AE, Ndubuaku UM, Baiyeri KP (2015) Media effects on emergence and growth of Moringa (Moringa oleifera Lam) seedlings in the nursery. Am J Exp Agric 7:181-189. https://doi.org/10.9734/ AJEA/2015/13602 
Estefan G, Sommer R, Ryan J (2013) Methods of soil, plant, and water analysis. A manual for the West Asia and North Africa region, 3rd edn. Beirut, Lebanon: International Center for Agricultural Research in the Dry Areas (ICARDA). https://hdl.handl e.net/20.500.11766/7512

Ghosal S, Moulik S (2015) Use of rice husk ash as partial replacement with cement in concrete-a review. Int J Eng Res 4:506-509. https ://doi.org/10.17950/ijer/v4s9/907

Gu S, Guan W, Beck JE (2017) Strawberry cultivar evaluation under high-tunnel and organic management in North Carolina. HortTechnology 27:84-92. https://doi.org/10.21273/HORTTECH03 559-16

Hossain SS, Mathur L, Roy P (2018) Rice husk/rice husk ash as an alternative source of silica in ceramics: a review. J Asian Ceram Soc 6:299-313. https://doi.org/10.1080/21870764.2018.1539210

Islabão GO, Vahl LC, Timm LC, Paul DL, Kath AH (2014) Rice husk ash as corrective of soil acidity. Revista Brasileira de Ciência do Solo 38:934-941. https://doi.org/10.1590/S0100-0683201400 0300025

Jeon W-T, Seong K-Y, Lee J-K, Oh I-S, Lee Y-H, Ok Y-S (2010) Effects of green manure and carbonized rice husk on soil properties and rice growth. Korean J Soil Sci Fertilizer 43:484-489

Mackenzie BD, Auld TD, Keith DA, Hui FK, Ooi MK (2016) The effect of seasonal ambient temperatures on fire-stimulated germination of species with physiological dormancy: a case study using Boronia (Rutaceae). PLoS One 11:e0156142. https://doi. org/10.1371/journal.pone.0156142

Major J, Rondon M, Molina D, Riha SJ, Lehmann J (2010) Maize yield and nutrition during 4 years after biochar application to a Colombian savanna oxisol. Plant Soil 333:117-128. https://doi. org/10.1007/s11104-010-0327-0

Mishra A, Taing K, Hall MW, Shinogi Y (2017) Effects of rice husk and rice husk charcoal on soil physicochemical properties, rice growth and yield. Agric Sci 8:1014-1032. https://doi.org/10.4236/ as.2017.89074

Munda S, Nayak A, Mishra P, Bhattacharyya P, Mohanty S, Kumar A, Kumar U, Baig M, Tripathi R, Shahid M, Adak T, Thilagam V (2016) Combined application of rice husk biochar and fly ash improved the yield of lowland rice. Soil Res 54:451-459. https:// doi.org/10.1071/SR15295

O'Connell S, Rivard C, Peet MM, Harlow C, Louws F (2012) High tunnel and field production of organic heirloom tomatoes: yield, fruit quality, disease, and microclimate. HortScience 47:1283-1290. https://doi.org/10.21273/HORTSCI.47.9.1283
Rekika D, Stewart KA, Boivin G, Jenni S (2008) Floating rowcovers improve germination and reduce carrot weevil infestations in carrot. HortScience 43:1619-1622. https://doi.org/10.21273/HORTS CI.43.5.1619

Seljåsen R, Lea P, Torp T, Riley H, Berentsen E, Thomsen M, Bengtsson GB (2012) Effects of genotype, soil type, year and fertilisation on sensory and morphological attributes of carrots (Daucus carota L.). J Sci Food Agric 92:1786-1799. https://doi.org/10.1002/ jsfa. 5548

Seljåsen R, Kristensen HL, Lauridsen C, Wyss GS, Kretzschmar U, Birlouez-Aragone I, Kahl J (2013) Quality of carrots as affected by pre-and postharvest factors and processing. J Sci Food Agric 93:2611-2626. https://doi.org/10.1002/jsfa.6189

Smith MR, Rao IM, Merchant A (2018) Source-sink relationships in crop plants and their influence on yield development and nutritional quality. Front Plant Sci 9:1889. https://doi.org/10.3389/ fpls.2018.01889

Soil Survey Staff (2014) Keys to soil taxonomy, 12th edn. USDANatural Resources Conservation Service, Washington

Sudeshika WAA, Pradheeban L, Nishanthan K, Sivachandiran S (2018) Effect of different rooting media on growth and yield performances of carrot (Daucus carota). Int J Agron Agric Res $12: 31-38$

Taiz L, Zeiger E (2014) Plant physiology. Sunderland Sinauer Associates, Sunderland

Varela MO, Rivera EB, Huang W-J, Chien C, Wang Y-M (2013) Agronomic properties and characterization of rice husk and wood biochars and their effect on the growth of water spinach in a field test. J Soil Sci Plant Nutr 13:251-266. https://doi.org/10.4067/S0718 $-95162013005000022$

York LM, Carminati A, Mooney SJ, Ritz K, Bennett MJ (2016) The holistic rhizosphere: integrating zones, processes, and semantics in the soil influenced by roots. J Exp Bot 67:3629-3643. https:// doi.org/10.1093/jxb/erw 108

$\mathrm{Yu} \mathrm{J,} \mathrm{Wu} \mathrm{J} \mathrm{(2018)} \mathrm{The} \mathrm{sustainability} \mathrm{of} \mathrm{agricultural} \mathrm{development}$ in China: the agriculture-environment nexus. Sustainability 10(6):1776. https://doi.org/10.3390/su10061776

Publisher's Note Springer Nature remains neutral with regard to jurisdictional claims in published maps and institutional affiliations. 